\title{
Perbaikan Line Balancing Proses Packing Tablet XYZ Menggunakan Metode Ranked Positional Weight di PT. Y
}

\author{
Hana Sekar Ayu Edy Purwanto*) dan Rahmaniyah Dwi Astuti \\ Program Studi Teknik Industri, Fakultas Teknik, Universitas Sebelas Maret, \\ Jl. Ir. Sutami 36 A, Kentingan, Surakarta, 51726
}

DOI: 10.20961/performa.18.1.32360

\begin{abstract}
Abstrak
PT. Y merupakan perusahaan di bidang industri farmasi yang memproduksi obat jadi. Berdasarkan pengamatan pada bagian packing produk Tablet XYZ, masih ditemukan adanya bottleneck antar stasiun kerja yang disebabkan oleh kurang meratanya pembagian kerja. Stasiun kerja yang beban kerjanya belum merata, dapat menyebabkan rendahnya line efficiency (keseimbangan lintasan). Penelitian ini melakukan perbaikan line balancing dengan metode Ranked Positional Weight yang bertujuan untuk meningkatkan nilai line efficiency dari proses packing Tablet XYZ. Hasil dari penelitian ini adalah adanya peningkatan nilai line efficiency setelah dilakukan pembagian elemen kerja yang merata.
\end{abstract}

Kata kunci: line balancing, line efficiency, ranked positional weight, produktivitas

\begin{abstract}
PT. $Y$ is a company in the pharmaceutical industry that produces finished drugs. Based on observations in the packing process of Tablet XYZ products, it is still found that there are bottlenecks between work stations caused by a lack of equal distribution of work. Work stations whose workload is not evenly distributed, can cause the low of line efficiency. This study improved line balancing using the Ranked Positional Weight method which aims to increase the line efficiency value of the Tablet XYZ packing process. The result of this study is an increase in the value of line efficiency after the distribution of work elements is evenly distributed.
\end{abstract}

Keywords: line balancing, line efficiency, ranked positional weight, productivity

\section{Pendahuluan}

Di era globalisasi saat ini, di setiap bidang bisnis sangat kompetitif. Semua industri yang terjun ke dalam dunia bisnis dituntut untuk mampu bersaing dengan baik supaya dapat memenangkan persaingan dan tujuan dari perusahaan tercapai dengan baik. Dalam menghadapi persaingan global ini, diperlukan adanya adanya efisiensi, efektivitas, dan produktivitas yang tepat supaya dapat bersaing secara kompetitif.

Salah satu industri yang persaingan bisnisnya cukup ketat di Indonesia adalah industri farmasi. Industri farmasi mempunyai market share yang baik (perusahaan farmasi domestik mendominasi pasar Indonesia). Pertumbuhan pasar farmasi di Indonesia meningkat setiap tahun dan kondisi ini membuat Indonesia mentransformasikannya sebagai pasar yang berkembang baru di Asia.

PT. Y merupakan perusahaan di bidang industri farmasi yang memproduksi obat jadi. Perusahaan ini telah berhasil mengembangkan produk sendiri yang dikembangkan oleh departemen Resources and Development. PT. Y merupakan perusahaan farmasi yang memiliki dua sistem manufaktur, yaitu Make to Stock (MTS) dan Make to Order (MTO). MTS adalah tipe industri yang membuat produk akhir untuk disimpan. Kebutuhan konsumen diambil dari persediaan di gudang. Ciri-ciri Make to Stock: standard item, high volume, terus menerus dibuat lalu disimpan, harga wajar, pengiriman dapat dilakukan segera, customer tidak mau menunggu, dan perlu adanya safety stock untuk mengatasi fluktuasi. Make To Order adalah tipe industri yang membuat produk hanya untuk memenuhi pesanan. Ciri-ciri Make to Order: inputnya bahan baku, biasanya untuk supply item dengan banyak jenis, harganya cukup mahal, lead time ditetapkan oleh konsumen/pesaing, dan perlu keahlian khusus, Komponen bisa dibeli untuk persediaan. (Dzikrillah, Purba, Suwazan, \& Wahjoedi, 2016).

PT. Y perlu meningkatkan produktivitas untuk mencapai target waktu yang diinginkan. Perusahaan ini memiliki 3 bagian pada Departemen Produksi, yaitu bagian produksi produk injeksi, bagian produksi produk tablet, dan bagian pengemasan (packing). Pengamatan dilakukan di PT. Y bagian packaging pada produk

*Korespondensi : hannasekarayu@gmail.com (correspondence author) 
Tablet XYZ. Permasalahan yang ditemui pada proses packing produk Tablet XYZ adalah bottleneck. Keseimbangan lintasan berhubungan erat dengan produksi masal. Waktu yang diijinkan untuk menyelesaikan elemen pekerjaan tersebut ditentukan oleh kecepatan lintas perakitan. Semua stasiun kerja sedapat mungkin harus memiliki waktu siklus yang sama. Bila stasiun kerja memiliki waktu siklus dibawah waktu idealnya, maka stasiun kerja tersebut memiliki waktu menganggur. Tujuan akhir dari line balancing adalah untuk meminimasi waktu menganggur ditiap stasiun kerja, sehingga dicapai efisiensi kerja yang tinggi pada stasiun kerja. (Nasution, 1999). Metode umum yang digunakan untuk mengoptimalkan nilai line efficiency produksi adalah metode Ranked Positional Weights (RPW) (Wignjosoebroto, 2000). Metode ini menggunakan sistem alokasi terhadap sejumlah mesin yang dialokasikan dalam suatu stasiun kerja. Cara kerja dari metode ini adalah menghitung bobot dari setiap mesin dan operator yang terdapat di dalam sistem. Bobot tersebut diurutkan dari yang terbesar hingga yang terkecil (Fudianto \& Munir, 2017).

Untuk dapat memilih dan menentukan metode yang tepat dalam penyeimbangan line balancing perlu dikembangkan metode analisis guna mengetahui performansi masing-masing metode yang ada terhadap karakteristik pengerjaan produksi, sehingga akan dapat ditentukan metode penyusunan stasiun kerja yang paling efisien. Dalam laporan ini, akan dibahas metode line balancing Helgeson-Birnie atau Ranked Positional Weight (RPW). (Baroto, 2002). Metode Ranked Positional Weight merupakan metode gabungan dari metode Largest Candidate Rules dengan metode Region Approach (Djunaidi \& Angga, 2017).

Oleh karena itu pada penelitian ini dibahas perbaikan line balancing yang diharapkan mampu meningkatkan produktivitas. Metode yang digunakan dalam penyusunan perbaikan line balancing ini adalah Ranked Positional Weights (RPW) yang terfokus pada penghitungan bobot dari setiap mesin dan operator yang terdapat di dalam proses packing. Bobot tersebut diurutkan dari yang terbesar hingga yang terkecil. Penelitian ini bertujuan untuk meningkatkan nilai line efficiency proses packing Tablet XYZ serta meningkatkan produktivitas produksi Tablet XYZ.

\section{Metode Penelitian}

\subsection{Tahap Identifikasi Awal}

Tahap identifikasi awal ini berisi latar belakang masalah, perumusan masalah, penentuan tujuan, batasan masalah, dan asumsi yang digunakan dalam melakukan penelitian.

\subsubsection{Studi Lapangan}

Studi lapangan dilakukan di lingkungan pabrik PT. Y. Observasi secara umum dilakukan pada keseluruhan lingkungan pabrik, dan secara khusus pada lingkungan Departemen Produksi bagian Packaging. Obervasi awal ini bertujuan untuk mengetahui jalannya proses pengemasan Tablet XYZ.

\subsubsection{Studi Literatur}

Studi literatur merupakan kegiatan untuk mencari informasi tentang segala hal yang berhubungan dengan penelitian ini. Informasi tersebut berupa tinjauan umum perusahaan yang terdiri dari sejarah perusahaan, visi dan misi perusahaan, lokasi perusahaan, struktur organisasi, serta proses produksi. Selain itu terdapat informasi mengenai landasan teori tentang line balancing. Studi literatur ini bertujuan untuk mendapatkan informasi yang lebih akurat secara teoritis yang digunakan untuk menunjang penyelesaian masalah yang akan diangkat dalam penelitian.

\subsubsection{Identifikasi Masalah}

Identifikasi masalah dilakukan setelah melakukan observasi awal dan mencari beberapa studi literatur. Pengidentifikasian masalah dilakukan di Departemen Produksi bagian Packaging pada Tablet XYZ dengan memahami proses Tablet XYZ serta mengidentifikasi faktor-faktor yang mempengaruhi bottleneck pada Tablet XYZ dengan obeservasi secara langsung pada line packing.

\subsubsection{Perumusan Masalah}

Rumusan masalah ditetapkan pada tahap ini untuk memberi batasan yang jelas mengenai hal apa saja yang akan dibahas dalam penelitian. Rumusan masalah tersebut diantaranya adalah bagaimana menentukan penyebab bottleneck pada line packing di Departemen Produksi PT. Y, bagaimana line efficiency awal yang ada pada Tablet XYZ, bagaimana merancang line balancing usulan yang ada di PT. Y, dan bagaimana perbandingan line balancing packing awal dan usulan pada Tablet XYZ di PT. Y.

\subsubsection{Penentuan Tujuan dan Manfaat}

Langkah penelitian yang selanjutnya adalah penentuan tujuan dan manfaat dari penelitian. Penentuan tujuan penelitian dilakukan agar masalah yang dikaji focus dan tidak menyebar ke hal yang lain. Sedangkan penentuan manfaat digunakan untuk menunjukkan manfaat yang didapatkan dari kerja praktek di PT. Y bagi perusahaan, universitas, maupun mahasiswa. 


\subsubsection{Penentuan Batasan Masalah}

Batasan masalah bertujuan untuk membatasi permasalahan yang dikaji dalam laporan kerja praktek sehingga permasalahan yang diangkat tidak terlalu kompleks untuk diselesaikan dalam pengolahan data. Batasan masalah yang digunakan antara lain pengukuran waktu proses yang dilakukan operator menggunakan pengukuran waktu kerja secara langsung dengan alat ukur stopwatch dan data yang digunakan adalah periode bulan Februari 2019.

\subsubsection{Penentuan Asumsi}

Asumsi merupakan dugaan atau anggapan sementara yang belum terbukti yang digunakan dalam penyusunan laporan kerja praktek. Asumsi yang digunakan adalah operator setiap stasiun kerja dianggap memiliki skill dengan rating performance yang sama.

\subsection{Tahap Pengumpulan dan Pengolahan Data}

Tahap ini terdiri dari pengumpulan data dan pengolahan data.

\subsection{Tahap Pengumpulan Data}

Tahap ini dilakukan pengumpulan data-data yang digunakan untuk menyelesaikan masalah. Data-data yang digunakan merupakan data relevan yang terkait dengan permasalahan yang diangkat. Data tersebut antara lain:

\section{Proses produksi}

Proses produksi merupakan informasi mengenai proses dalam memproduksi Tablet XYZ.

2. Data waktu siklus lini produksi

Data waktu siklus diperoleh dari pengukuran waktu kerja secara langsung pada masing-masing stasiun kerja.

\subsection{Tahap Pengolahan Data}

Pengolahan data digunakan untuk mengolah data-data yang sudah dikumpulkan untuk dilakukan analisis dan interpretasi hasilnya. Adapun langkah-langkah dalam pengolahan data yang dilakukan dalam lapiran kerja praktek ini adalah uji kecukupan data, perhitungan waktu baku, perhitungan line efficiency awal, kemudian menentukan penyebab terjadinya bottleneck dengan menggunakan fishbone diagram. Setelah dapat mengidentifikasi masalah, memberikan usulan perbaikan terhadap line efficiency untuk produk Tablet XYZ supaya dapat meningkatkan nilai line efficiency produk tersebut, serta melakukan perbandingan antara nilai line efficiency awal dengan nilai line efficiency usulan.

\subsection{Tahap Analisis dan Interpretasi Hasil}

Analisis hasil dari penelitian yang telah dilakukan yang menjelaskan mengenai analisis perhitungan line efficiency awal pada Tablet XYZ, analisis penyebab terjadinya bottleneck pada line packing, analisis perhitungan line efficiency usulan pada Tablet XYZ, serta analisis tabel perbandingan line efficiency awal dan line efficiency usulan pada Tablet XYZ.

\subsection{Tahap Kesimpulan dan Saran}

Pengumpulan dan pengolahan data serta analisis yang telah dilakukan, maka tahap selanjutnya adalah membuat kesimpulan, kesimpulan dari penelitian ini menjawab tujuan yang ingin dicapai. Setelah mendapatkan kesimpulan dari penilitian ini, maka peneliti membuat saran yang diharapkan bermanfaat bagi perusahaan dan penelitian selanjutnya.

Perhitungan line balancing dapat dilakukan dengan menghitung :

- Cycle time (Ws) (Montororing, 2018) adalah waktu yang digunakan dalam melakukan suatu elemen kerja tanpa mempertimbangkan aspek kecepatan kerja dan kelonggaran. Untuk menghitung waktu siklus, rumusnya seperti berikut:

$\bar{x}=\frac{\sum \mathrm{x}_{\mathrm{i} \mathrm{n}}}{\sum \text { Sub grup }}$

- Idle time (Rachman, 2015) adalah waktu dimana operator atau pekerja menunggu untuk melakukan proses atau pekerjaan selanjutnya yang akan dikerjakan.

Rumus :

Idle Time $=n W s-\sum W i$

- Efisiensi Stasiun Kerja (Rachman, 2015) adalah rasio antara waktu operasi setiap stasiun kerja (Wi) dengan waktu operasi stasiun kerja terbesar (Ws)

Rumus :

Efisiensi stasiun kerja $=\frac{W i}{W S} \times 100 \%$ 
- Line efficiency (LE) (Sutalaksana, 2006) adalah berapa lama waktu yang dibutuhkan untuk menyelesaikan satu proses produksi.

Rumus :

Line Efficiency $=\frac{\sum W i}{K \cdot C T} \times 100 \%$

Keterangan:

$\mathrm{Wi}=$ waktu stasiun ke-i

$\mathrm{K}=$ jumlah total stasiun

$\mathrm{CT}=$ waktu siklus terpanjang

- Balance delay (Rachman, 2015) adalah Ukuran dari ketidakefisienan lintasan yang dihasilkan dari waktu menganggur sebenarnya.

Rumus :

$D=1-$ Line Efficiency

- Smoothness Index adalah indeks yang menunjukkan kelancaran relatif dari penyeimbangan lini perakitan tertentu.

Rumus :

$$
S I=\sqrt{\sum_{i=1}^{k}(W s-W i)^{2}}
$$

Penelitian ini dalam menghitung line efficiency menggunakan waktu standar/waktu baku. Berikut ini merupakan langkah-langkah untuk menghitung waktu standar / waktu baku :

- Uji Kecukupan Data

Uji kecukupan data adalah proses pengujian yang dilakukan terhadap data pengukuran untuk mengetahui apakah data yang diambil untuk penelitian sudah mencukupi untuk dilakukan perhitungan waktu siklus. Pengujian kecukupan data dipengaruhi oleh factor-faktor sebagai berikut (Sutalaksana, 2006):

a. Tingkat ketelitian

Tingkat ketelitian menunjukkan penyimpangan maksimum dari hasil perhitungan terhadap nilai waktu sebenarnya.

b. Tingkat kepercayaan

Tingkat kepercayaan menunjukkan besarnya probabilitas bahwa data sudah diambil berada dalam tingkat ketelitian yang sebelumnya telah ditentukan.

Rumus untuk menguji kecukupan data pengamatan dapat menggunakan persamaan sebagai berikut..

$N^{\prime}=\left(\frac{\frac{k}{s} \sqrt{N\left(\Sigma X i^{2}\right)-(\Sigma X i)^{2}}}{\Sigma X}\right)$

Keterangan:

$\mathrm{N}^{\prime} \quad$ = Jumlah pengukuran yang diperlukan

$\mathrm{N}=$ Jumlah pengukuran yang telah dilakukan

$\mathrm{K} \quad=$ Tingkat keyakinan

$\mathrm{s} \quad=$ Tingkat ketelitian

$X_{\tilde{i}} \quad=$ Data ke-i

- Menghitung Waktu Normal (Wn)

Waktu normal dihitung dengan cara perkalian antara faktor penyesuaian dengan nilai rata-rata waktu siklus. (Montororing, 2018).

$W n=W s X P$

Dimana :

$W n=$ Waktu Normal

Ws $=$ Waktu siklus

$P=$ Faktor penyesuaian 
- Menghitung Waktu Baku

Waktu baku (Montororing, 2018) adalah waktu yang diperlukan oleh manusia untuk menyelesaikan suatu pekerjaan secara tuntas. Waktu baku sudah mempertimbangkan aspek kecepatan kerja operator dan kelonggaran yang dibutuhkan oleh operator.

$\mathrm{Wb}=\mathrm{Wn} \mathrm{X}(1+\mathrm{A})$

Dimana :

Wn $=$ Waktu Normal

A = Kelonggaran

- Menentukan penyesuaian Rating Performance

Rating Perfomance adalah kegiatan evaluasi kecepatan atau tempo kerja operator pada saat pengukuran kerja berlangsung. Kecepatan usaha, tempo maupun performance kerja semuanya menunjukkan kecepatan gerakan operator pada saat bekerja.. Penyesuaian yang digunakan penelitian ini adalah westinghouse.

\section{Hasil dan Pembahasan}

Untuk melakukan packing pada Tablet XYZ, terdapat 27 proses yang harus dilalui. Setelah setiap proses dan waktunya diketahui, maka dibuat precedence diagram seperti yang ditunjukkan pada Gambar 1.

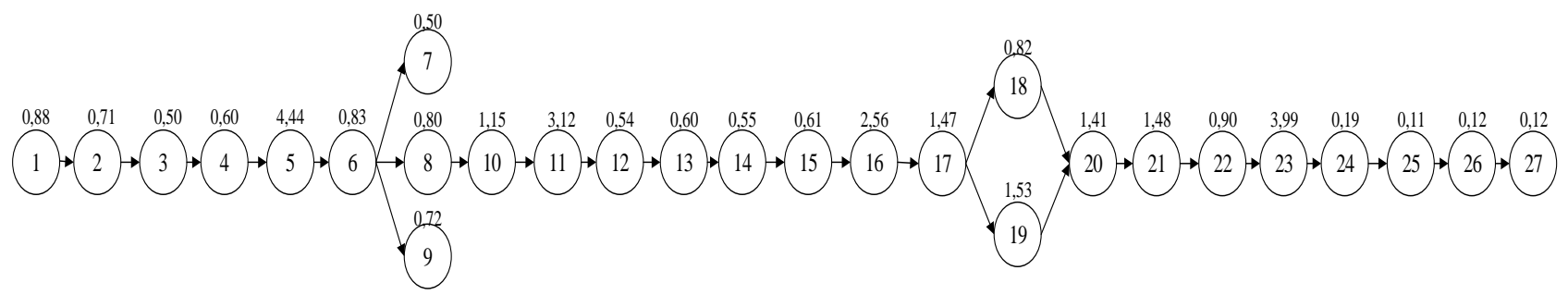

Gambar 1. Precedence Diagram Awal Tablet XYZ

Untuk mencapai produktivitas supaya perusahaan dapat menghasilkan output sesuai dengan target yang telah ditentukan, diperlukan ukuran kegiatan pelaksanaan kegiatan proses berdasarkan data yang telah diolah dengan menerapkan metode line balancing yang sesuai. Sebelumnya, dilakukan beberapa pengujian secara ilmiah, sehingga dapat dijadikan suatu ukuran penerapan line balancing yang baik.

Untuk mengetahui kecukupan data pada proses packing yang telah diambil, maka dilakukan uji kecukupan data dengan tingkat keyakinan 95\% dan tingkat ketelitian 5.

Tabel 1. Uji Kecukupan Data

\begin{tabular}{|c|c|c|c|c|c|c|c|c|c|c|c|}
\hline \multirow{2}{*}{ Stasiun } & \multirow{2}{*}{ No. } & \multirow{2}{*}{ Elemen Kerja } & \multicolumn{5}{|c|}{ Ws (detik) } & \multirow{2}{*}{ Jumlah } & \multirow{2}{*}{$\begin{array}{l}\text { Rata- } \\
\text { rata }\end{array}$} & \multirow{2}{*}{$\mathbf{N}^{\prime}$} & \multirow{2}{*}{ Keterangan } \\
\hline & & & 1 & 2 & 3 & 4 & 5 & & & & \\
\hline \multirow{3}{*}{1} & 1 & Menata strip & 0,87 & 0,79 & 0,99 & 0,88 & 0,86 & 4,39 & 0,88 & 3 & CUKUP \\
\hline & 2 & Mengambil strip & 0,83 & 0,68 & 0,63 & 0,73 & 0,66 & 3,53 & 0,71 & 4 & CUKUP \\
\hline & 3 & Meletakkan strip ke conveyor & 0,54 & 0,55 & 0,47 & 0,42 & 0,51 & 2,49 & 0,50 & 4 & CUKUP \\
\hline 2 & 1 & Printing 1 & 0,6 & 0,6 & 0,6 & 0,6 & 0,6 & 3 & 0,60 & 0 & CUKUP \\
\hline \multirow{2}{*}{3} & 1 & Sorting out 1 & 4,15 & 4,38 & 3,72 & 5,28 & 4,65 & 4,16 & 4,44 & 4 & CUKUP \\
\hline & 2 & Pembundelan & 0,89 & 0,88 & 0,73 & 0,75 & 0,91 & 22,18 & 0,83 & 5 & CUKUP \\
\hline \multirow{6}{*}{4} & 1 & Mengambil folding box & 0,57 & 0,53 & 0,53 & 0,47 & 0,41 & 2,51 & 0,50 & 4 & CUKUP \\
\hline & 2 & Mengambil strip & 0,84 & 0,72 & 0,81 & 0,75 & 0,9 & 4,02 & 0,80 & 3 & CUKUP \\
\hline & 3 & Mengambil brosur & 0,72 & 0,71 & 0,84 & 0,68 & 0,65 & 3,6 & 0,72 & 4 & CUKUP \\
\hline & 4 & Memasukkan strip dan brosur ke dalam folding box & 1,12 & 1,21 & 1,37 & 0,97 & 1,06 & 5,73 & 1,15 & 5 & CUKUP \\
\hline & 5 & Melipat folding box & 3,25 & 3,27 & 2,44 & 3,03 & 3,59 & 15,58 & 3,12 & 5 & CUKUP \\
\hline & 6 & Meletakkan produk ke conveyor & 0,62 & 0,49 & 0,5 & 0,56 & 0,53 & 2,7 & 0,54 & 3 & CUKUP \\
\hline 5 & 1 & Printing 2 & 0,6 & 0,6 & 0,6 & 0,6 & 0,6 & 3 & 0,60 & 0 & CUKUP \\
\hline 6 & 1 & Check Wayer & 0,55 & 0,55 & 0,55 & 0,55 & 0,55 & 2,75 & 0,55 & 0 & CUKUP \\
\hline \multirow[b]{2}{*}{7} & 1 & Sorting out 2 & 0,57 & 0,59 & 0,73 & 0,52 & 0,65 & 3,06 & 0,61 & 5 & CUKUP \\
\hline & 2 & Menata produk & 2,81 & 2,36 & 2,09 & 2,98 & 2,56 & 12,8 & 2,56 & 5 & CUKUP \\
\hline \multirow{4}{*}{8} & 1 & Mengambil produk & 1,16 & 1,48 & 1,56 & 1,65 & 1,49 & 7,34 & 1,47 & 5 & CUKUP \\
\hline & 2 & Melekatkan stiker label bagian samping kanan & 0,99 & 0,69 & 0,77 & 0,79 & 0,85 & 4,09 & 0,82 & 5 & CUKUP \\
\hline & 3 & Melekatkan stiker label bagian samping kiri & 1,59 & 1,67 & 1,33 & 1,67 & 1,39 & 7,65 & 1,53 & 4 & CUKUP \\
\hline & 4 & Memposisikan kemasan & 1,15 & 1,25 & 1,57 & 1,56 & 1,52 & 7,05 & 1,41 & 5 & CUKUP \\
\hline \multirow{3}{*}{9} & 1 & Mengambil master box & 1,36 & 1,69 & 1,42 & 1,57 & 1,35 & 7,3833 & 1,48 & 4 & CUKUP \\
\hline & 2 & Memasukkan produk ke dalam master box & 0,88 & 0,85 & 1,00 & 0,88 & 0,87 & 4,49 & 0,90 & 2 & CUKUP \\
\hline & 3 & Memposisikan master box & 3,93 & 3,55 & 3,56 & 4,77 & 4,15 & 19,96 & 3,99 & 5 & CUKUP \\
\hline \multirow{4}{*}{10} & 1 & Menyegel master box & 0,20 & 0,22 & 0,18 & 0,20 & 0,16 & 0,96 & 0,19 & 5 & CUKUP \\
\hline & 2 & Menimbang master box & 0,11 & 0,10 & 0,13 & 0,12 & 0,09 & 0,55 & 0,11 & 5 & CUKUP \\
\hline & 3 & Mencatat hasil penimbangan di master box & 0,10 & 0,10 & 0,13 & 0,12 & 0,13 & 0,58 & 0,12 & 4 & CUKUP \\
\hline & 4 & Meletakkan master box ke pallet & 0,10 & 0,13 & 0,12 & 0,11 & 0,13 & 0,59 & 0,12 & 4 & CUKUP \\
\hline
\end{tabular}


Berikut merupakan contoh perhitungan Uji Kecukupan Elemen Kerja 1 Stasiun 1:

Nilai $k=2, s=0,5$

$\mathrm{N}^{\prime}=\left(\frac{\sqrt[k]{\sigma^{2}} \sqrt{N\left(\Sigma W s^{2}\right)-\left(\sum W s\right)^{2}}}{\Sigma x}\right)$

$N^{\prime}=\left(\frac{\frac{2}{0,5} \sqrt{5(3,88)-(19,27)}}{4,39}\right)$

$\mathrm{N}^{\prime}=3$

Berdasarkan hasil perhitungan kecukupan data dari 27 elemen kerja pada 10 stasiun kerja, didapatkan bahwa semua elemen kerja telah mencukupi kebutuhan data yaitu kurang atau sama dengan 5. Semua data yang diambil telah mencukupi kebutuhan data karena hasil pengamatan memiliki waktu yang tidak bervariasi atau stabil.

Data waktu operasi yang telah diambil dan lulus uji kecukupan data tersebut kemudian diolah sehingga diperoleh waktu standar atau waktu baku dengan memperhatikan rating factor dan allowance. Rating factor yang digunakan adalah westinghouse dan allowance berdasarkan faktor-faktor yang berpengaruh. Rekapitulasi hasil perhitungan waktu baku dapat dilihat pada Tabel 2. Tabel 2 menjelaskan bahwa untuk masingmasing elemen kerja dihitung waktu bakunya berdasarkan faktor penyesuaian dan faktor kelonggaran. Disini, dilakukan asumsi bahwa semua skill operator dianggap rata-rata.

Tabel 2. Perhitungan Nilai Penyesuaian pada Tablet XYZ

\begin{tabular}{|c|l|c|c|c|c|c|c|}
\hline \multirow{2}{*}{ No Elemen Kerja } & \multirow{2}{*}{ Nilai Penyesuaian } & \multirow{2}{*}{ Jumlah } & \multirow{2}{*}{ Penyesuaian } \\
\cline { 3 - 7 } & & Skill & Effort & Condition & Consistency & & \\
\hline 1 & Menata strip & 0 & 0,02 & $-0,03$ & 0,03 & 0,02 & 1,02 \\
\hline 2 & Mengambil strip & 0 & 0,05 & $-0,03$ & 0,03 & 0,05 & 1,05 \\
\hline 3 & Meletakkan strip ke conveyor & 0 & 0,02 & $-0,03$ & 0,03 & 0,02 & 1,02 \\
\hline 4 & Printing 1 & 0 & 0 & $-0,03$ & 0,03 & 0 & 1 \\
\hline 5 & Sorting out 1 & 0 & 0,02 & $-0,03$ & 0,03 & 0,02 & 1,02 \\
\hline 6 & Pembundelan & 0 & 0,05 & $-0,03$ & 0,01 & 0,03 & 1,03 \\
\hline 7 & Mengambil folding box & 0 & 0,05 & $-0,03$ & 0,03 & 0,05 & 1,05 \\
\hline 8 & Mengambil strip & 0 & 0,05 & $-0,03$ & 0,01 & 0,03 & 1,03 \\
\hline 9 & Mengambil brosur & 0 & 0,05 & $-0,03$ & 0,01 & 0,03 & 1,03 \\
\hline 10 & Memasukkan strip dan brosur ke dalam folding box & 0 & 0,05 & $-0,03$ & 0,01 & 0,03 & 1,03 \\
\hline 11 & Melipat folding box & 0 & 0,05 & $-0,03$ & 0,03 & 0,05 & 1,05 \\
\hline 12 & Meletakkan produk ke conveyor & 0 & 0,02 & $-0,03$ & 0,03 & 0,02 & 1,02 \\
\hline 13 & Printing 2 & 0 & 0 & $-0,03$ & 0,03 & 0 & 1 \\
\hline 14 & Check Wayer & 0 & 0 & $-0,03$ & 0,03 & 0 & 1 \\
\hline 15 & Sorting out 2 & 0 & 0,02 & $-0,03$ & 0,03 & 0,02 & 1,02 \\
\hline 16 & Menata produk & 0 & 0,05 & $-0,03$ & 0,03 & 0,05 & 1,05 \\
\hline 17 & Mengambil produk & 0 & 0,02 & $-0,03$ & 0,03 & 0,02 & 1,02 \\
\hline \hline 18 & Melekatkan stiker label bagian samping kanan & 0 & 0,05 & $-0,03$ & 0,01 & 0,03 & 1,03 \\
\hline 19 & Melekatkan stiker label bagian samping kiri & 0 & 0,05 & $-0,03$ & 0,01 & 0,03 & 1,03 \\
\hline 20 & Memposisikan kemasan & 0 & 0,02 & $-0,03$ & 0,03 & 0,02 & 1,02 \\
\hline 21 & Mengambil master box & 0 & 0,02 & $-0,03$ & 0,03 & 0,02 & 1,02 \\
\hline 22 & Memasukkan produk ke dalam master box & 0 & 0,05 & $-0,03$ & 0,03 & 0,05 & 1,05 \\
\hline 23 & Memposisikan master box & 0 & 0,02 & $-0,03$ & 0,03 & 0,02 & 1,02 \\
\hline 24 & Menyegel master box & 0 & 0,05 & $-0,03$ & 0,01 & 0,03 & 1,03 \\
\hline 25 & Menimbang master box & 0 & 0,05 & $-0,03$ & 0,03 & 0,05 & 1,05 \\
\hline 26 & Mencatat hasil penimbangan di master box & 0 & 0,05 & $-0,03$ & 0,03 & 0,05 & 1,05 \\
\hline 27 & Meletakkan master box ke pallet & 0 & 0,05 & $-0,03$ & 0,03 & 0,05 & 1,05 \\
\hline & & & & & & & \\
\hline
\end{tabular}


Waktu normal dihitung menggunakan data cycle time dan penyesuaian, besarnya penyesuaian tiap stasiun kerja berbeda-beda karena dihitung dengan menggunakan metode westinghouse yang memperhatikan skill, effort, kondisi lingkungan, dan consistency masing-masing operator. Setelah mendapatkan nilai penyesuaian ini kemudian dilakukan perhitungan waktu normal dengan mengalikan cycle time dan nilai penyesuaian. Berdasarkan waktu normal tersebut, dapat diperoleh nilai waktu baku yang merupakan waktu untuk mengerjakan elemen kerja dengan tenaga yang wajar, pada situasi dan kondisi yang normal masingmasing stasiun kerja. Perhitungan waktu baku ini menggunakan data waktu normal dan nilai allowance. Nilai allowance yang digunakan diasumsikan sebesar 10\% (manufaktur) untuk tiap stasiun kerjanya.

Berdasarkan hasil pengamatan yang telah dilakukan, maka diperoleh untuk masing-masing proses produksi besarnya waktu baku adalah sebagai berikut.

Tabel 3. Perhitungan Waktu Baku

\begin{tabular}{|c|c|c|c|c|c|}
\hline Elemen Kerja & Penyesuaian & $\begin{array}{c}\text { Waktu Normal } \\
\text { (detik) }\end{array}$ & Allowance & \multicolumn{2}{|c|}{$\begin{array}{l}\text { Waktu Baku } \\
\text { (detik) }\end{array}$} \\
\hline Menata strip & 1,02 & 0,90 & $10 \%$ & 1,00 & \multirow{3}{*}{2,38} \\
\hline Mengambil strip & 1,05 & 0,74 & $10 \%$ & 0,82 & \\
\hline Meletakkan strip ke conveyor & 1,02 & 0,51 & $10 \%$ & 0,56 & \\
\hline Printing 1 & 1 & 0,60 & $10 \%$ & 0,67 & 0,67 \\
\hline Sorting out 1 & 1,02 & 4,52 & $10 \%$ & 5,03 & \multirow{2}{*}{5,98} \\
\hline Pembundelan & 1,03 & 0,86 & $10 \%$ & 0,95 & \\
\hline Mengambil folding box & 1,05 & 0,53 & $10 \%$ & 0,59 & \multirow{6}{*}{7,89} \\
\hline Mengambil strip & 1,03 & 0,83 & $10 \%$ & 0,92 & \\
\hline Mengambil brosur & 1,03 & 0,74 & $10 \%$ & 0,82 & \\
\hline Memasukkan strip dan brosur ke dalam folding box & 1,03 & 1,18 & $10 \%$ & 1,31 & \\
\hline Melipat folding box & 1,05 & 3,27 & $10 \%$ & 3,64 & \\
\hline Meletakkan produk ke conveyor & 1,02 & 0,55 & $10 \%$ & 0,61 & \\
\hline Printing 2 & 1 & 0,60 & $10 \%$ & 0,67 & 0,67 \\
\hline Check Wayer & 1 & 0,55 & $10 \%$ & 0,61 & 0,61 \\
\hline Sorting out 2 & 1,02 & 0,62 & $10 \%$ & 0,69 & \multirow{2}{*}{3,68} \\
\hline Menata produk & 1,05 & 2,69 & $10 \%$ & 2,99 & \\
\hline Mengambil produk & 1,02 & 1,50 & $10 \%$ & 1,66 & \multirow{4}{*}{5,95} \\
\hline Melekatkan stiker label bagian samping kanan & 1,03 & 0,84 & $10 \%$ & 0,94 & \\
\hline Melekatkan stiker label bagian samping kiri & 1,03 & 1,58 & $10 \%$ & 1,75 & \\
\hline Memposisikan kemasan & 1,02 & 1,44 & $10 \%$ & 1,60 & \\
\hline Mengambil master box & 1,02 & 1,51 & $10 \%$ & 1,67 & \multirow{3}{*}{7,24} \\
\hline Memasukkan produk ke dalam master box & 1,05 & 0,94 & $10 \%$ & 1,05 & \\
\hline Memposisikan master box & 1,02 & 4,07 & $10 \%$ & 4,52 & \\
\hline Menyegel master box & 1,03 & 0,20 & $10 \%$ & 0,22 & \multirow{4}{*}{0,62} \\
\hline Menimbang master box & 1,05 & 0,12 & $10 \%$ & 0,13 & \\
\hline Mencatat hasil penimbangan di master box & 1,05 & 0,12 & $10 \%$ & 0,14 & \\
\hline Meletakkan master box ke pallet & 1,05 & 0,12 & $10 \%$ & 0,14 & \\
\hline $\begin{array}{c}\text { Total } \\
\end{array}$ & & 32,12 & & \multicolumn{2}{|c|}{35,69} \\
\hline
\end{tabular}

Berdasarkan perhitungan waktu baku tersebut, didapatkan bahwa antara stasiun kerja 2 dengan stasiun kerja 3 dan antara stasiun kerja 7 dengan stasiun kerja 8 memiliki selisih waktu yang besar, dimana hal tersebut berkemungkinan dapat menyebabkan penumpukan pada stasiun kerja 3 dan stasiun kerja 8 yang memiliki waktu lama dalam melakukan proses packing. 
Tabel 4. Perhitungan Efisiensi tiap Stasiun, Line Efficiency, Balance Delay, dan Idle Time pada Tablet XYZ

\begin{tabular}{|c|c|c|c|c|c|c|c|}
\hline No & $\begin{array}{c}\text { Stasiun } \\
\text { Kerja }\end{array}$ & $\begin{array}{c}\text { Waktu Baku } \\
\text { Stasiun (detik) }\end{array}$ & $\begin{array}{l}\text { Efisiensi } \\
\text { Stasiun }\end{array}$ & $\begin{array}{c}\text { Line } \\
\text { Efficiency }\end{array}$ & $\begin{array}{c}\text { Balance } \\
\text { Delay }\end{array}$ & Idle Time & $\begin{array}{c}\text { Smoothness } \\
\text { Index }\end{array}$ \\
\hline 1 & 1 & 2,38 & $30 \%$ & \multirow{10}{*}{$45,25 \%$} & \multirow{10}{*}{$54,75 \%$} & 5,51 & \multirow{10}{*}{16,31} \\
\hline 2 & 2 & 0,67 & $8 \%$ & & & 7,22 & \\
\hline 3 & 3 & 5,98 & $76 \%$ & & & 1,91 & \\
\hline 4 & 4 & 7,89 & $100 \%$ & & & 0,00 & \\
\hline 5 & 5 & 0,67 & $8 \%$ & & & 7,22 & \\
\hline 6 & 6 & 0,61 & $8 \%$ & & & 7,28 & \\
\hline 7 & 7 & 3,68 & $47 \%$ & & & 4,21 & \\
\hline 8 & 8 & 5,95 & $75 \%$ & & & 1,94 & \\
\hline 9 & 9 & 7,24 & $92 \%$ & & & 0,64 & \\
\hline 10 & 10 & 0,62 & $8 \%$ & & & 7,27 & \\
\hline & Minimum & 0,61 & & \multirow{3}{*}{\multicolumn{2}{|c|}{ Total Idle Time }} & 43,19 & \\
\hline & Maksimum & 7,89 & & & & & \\
\hline & Total & 35,69 & & & & & \\
\hline
\end{tabular}

Berdasarkan perhitungan tersebut, didapatkan bahwa pada setiap stasiun kerja memiliki nilai efisiensi dengan selisih yang sangat berbeda, maka hal tersebut dapat menyebabkan adanya penumpukan pada beberapa stasiun kerja yang ada.

Nilai balance delay yang diperoleh sebesar $54.75 \%$. Nilai balance delay tersebut sangatlah tinggi karena nilai balance delay lebih tinggi dibandingkan nilai line efficiency yang menunjukkan bahwa kerterlambatan dalam lintasan sangat tinggi, sehingga menyebabkan adanya penumpukan produk pada proses packing yang dilakukan.

Besarnya waktu menunggu atau idle time berpengaruh pada keseimbangan lini produksi. Semakin kecil nilai idle time maka semakin seimbang line packing pada produk tablet XYZ. Perhitungan idle time tersebut menunjukkan bahwa pada stasiun kerja 6 memiliki nilai idle time terbesar karena waktu baku pada stasiun ini sangatlah singkat. Sedangkan pada stasiun kerja 4 memiliki idle time paling kacil yaitu 0 detik dikarenakan waktu baku stasiun kerja ini memilki nilai yang paling besar dibandingkan stasiun kerja yang lain.

Perhitungan smothness index untuk menunjukkan suatu indeks yang menunjukkan kelancaran relatif dari suatu line. Besarnya nilai smoothness index pada line packing Tablet XYZ adalah 16.31 yang menunjukkan bahwa kelancaran pada stasiun-stasiun kerja tersebut masih kurang..

Dari hasil perhitungan berdasarkan waktu pengamatan, didapatkan nilai line efficiency pada Tablet XYZ sebesar $45.25 \%$. Nilai line efficiency tersebut sangatlah rendah sehingga produk yang dihasilkan sering melewati target waktu yang telah ditentukan oleh perusahaan. Line efficiency yang rendah berpotensi menyebabkan terjadinya bottleneck. Untuk melancarkan proses packing, maka diperlukan penanganan lebih lanjut. Diagram fishbone dapat digunakan untuk mengetahui factor-faktor penyebab terjadinya bottleneck tersebut. Berikut merupakan diagram fishbone mengenai faktor-faktor penyebab adanya cycle time yang besar sehingga terjadi bottleneck.

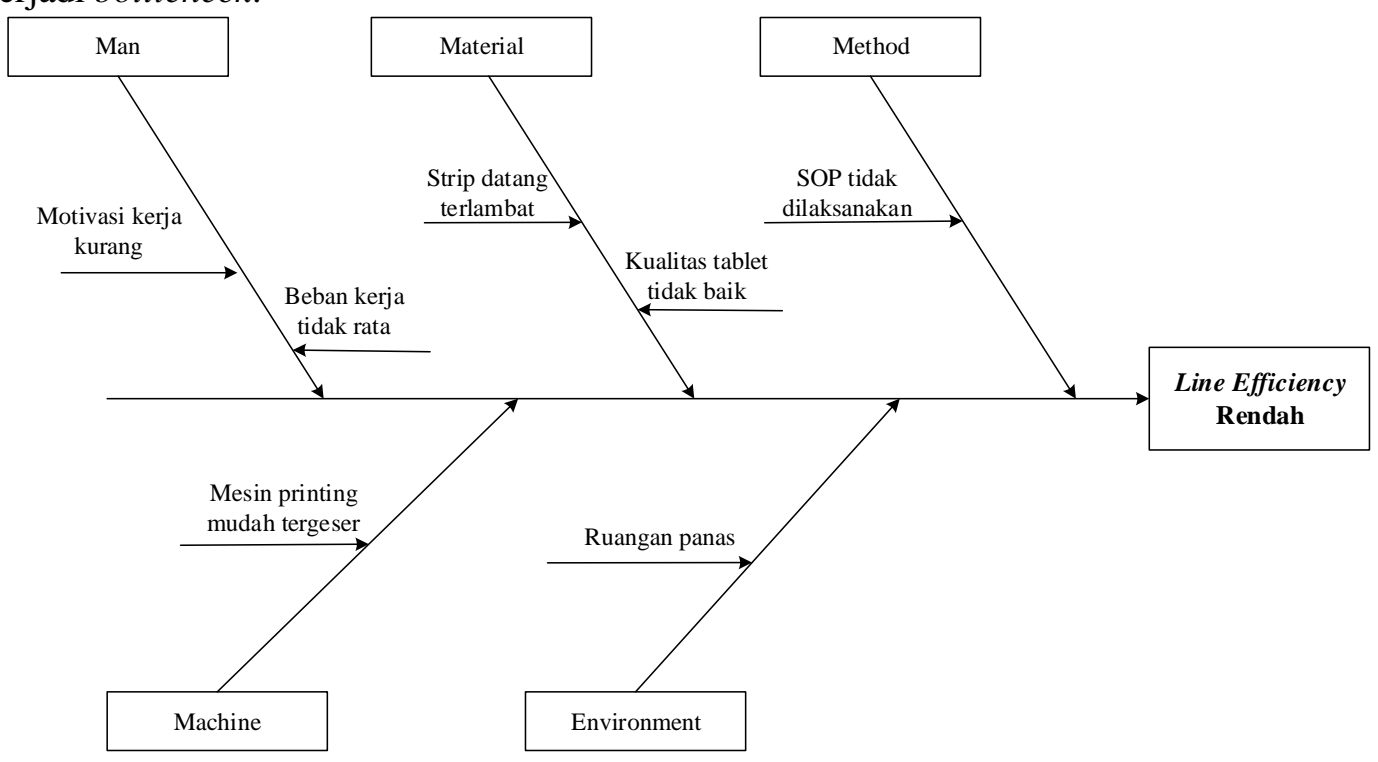

Gambar 2. Fishbone Diagram 
Berdasarkan hasil pengamatan langsung proses packing Tablet XYZ dapat dihasilkan fishbone diagram seperti Gambar 2. Faktor yang mempengaruhi rendahnya line efficiency adalah faktor man (manusia), material, machine (mesin), method (metode), dan environment (lingkungan). Pada faktor man terdapat dua faktor penyebab yaitu motivasi kerja kurang dan beban kerja tidak merata yang menyebabkan oprator memiliki beban kerja yang tinggi sehingga mudah mengalami kelelahan yang berakibat menurunkan produktivitas kerja. Faktor machine terdapat satu faktor penyebab yaitu mesin printing mudah tergeser sehingga hraus melakukan set up ulang yang memakan waktu. Faktor method terdapat satu faktor penyebab yaitu SOP yang telah dibuat perusahaan tidak diterapkan oleh operator sehingga menyebabkan terjadinya bottleneck. Pada faktor material terdapat dua faktor penyebab yaitu strip dating terlambat sehingga menyebabkan proses packing menjadi terhenti dan kualitas tablet yang tidak baik menyebabkan harus melakukan perbaikan dulu sehingga akan menghambat proses packing. Setelah itu, faktor environment terdapat satu faktor penyebab yaitu ruangan kerja yang panas sehingga operator kurang nyaman dalam melakukan pekerjaannya yang menyebabkan menurunnya produktivitas kerja.

Perbaikan line balancing proses packing dilakukan dengan menggunakan metode ranked prostional weight (RPW). Bobot posisi dilakukan dengan menghitung berdasarkan akumulasi elemen kerja yang mengikuti, seperti yang telah ditampilkan di precedence diagram. Berikut merupakan hasil pengurutan elemen kerja dengan bobot posisi.

Tabel 5. Urutan Elemen Kerja Berdasarkan Waktu Baku pada Tablet XYZ

\begin{tabular}{|c|c|c|c|}
\hline \multicolumn{4}{|c|}{ Urutan Elemen Kerja Berdasarkan Pembobotan } \\
\hline \multicolumn{2}{|c|}{ Sebelum } & \multicolumn{2}{|c|}{ Sesudah } \\
\hline $\begin{array}{c}\text { Elemen Kerja } \\
\text { Pendahulu }\end{array}$ & Jumlah & $\begin{array}{c}\text { Elemen Kerja } \\
\text { Pendahulu }\end{array}$ & Jumlah \\
\hline 1 & 35,69 & 1 & 35,69 \\
\hline 2 & 34,70 & 2 & 34,70 \\
\hline 3 & 33,87 & 3 & 33,87 \\
\hline 4 & 33,31 & 4 & 33,31 \\
\hline 5 & 33,31 & 5 & 33,31 \\
\hline 6 & 33,31 & 6 & 33,31 \\
\hline 7 & 24,92 & 8 & 25,25 \\
\hline 8 & 25,25 & 9 & 25,16 \\
\hline 9 & 25,16 & 7 & 24,92 \\
\hline 10 & 24,33 & 10 & 24,33 \\
\hline 11 & 23,02 & 11 & 23,02 \\
\hline 12 & 19,39 & 12 & 19,39 \\
\hline 13 & 18,77 & 13 & 18,77 \\
\hline 14 & 18,11 & 14 & 18,11 \\
\hline 15 & 17,50 & 15 & 17,50 \\
\hline 16 & 16,80 & 16 & 16,80 \\
\hline 17 & 13,82 & 17 & 13,82 \\
\hline 18 & 10,40 & 19 & 11,22 \\
\hline 19 & 11,22 & 18 & 10,40 \\
\hline 20 & 9,47 & 20 & 9,47 \\
\hline 21 & 7,87 & 21 & 7,87 \\
\hline 22 & 6,19 & 22 & 6,19 \\
\hline 23 & 5,15 & 23 & 5,15 \\
\hline 24 & 0,62 & 24 & 0,62 \\
\hline 25 & 0,40 & 25 & 0,40 \\
\hline 26 & 0,27 & 26 & 0,27 \\
\hline 27 & 0,14 & 27 & 0,14 \\
\hline
\end{tabular}

Urutan elemen kerja berdasar bobot posisi yang dihasilkan, akan digunakan sebagai dasar penentuan penugasan elemen kerja pada stasiun kerja. Penentuan jumlah stasiun kerja usulan yaitu berdasarkan urutan elemen kerja pada bobot posisi yang telah ditentukan. Berdasarkan perhitungan, didapatkan jumlah minimal stasiun kerja untuk proses packing usulan pada Tablet XYZ adalah sebanyak 5 stasiun kerja.

Tabel 6 merupakan usulan stasiun kerja yang berdasarkan hasil urutan elemen kerja dengan bobot posisi yang telah dihitung di Tabel 5. Setiap stasiun kerja memiliki waktu baku yang sama atau memiliki selisih yang sedikit tiap antar stasiun. Urutan elemen kerja yang dilakukan dilihat berdasarkan Tabel 5 dengan memperhatikan precedence diagram dan waktu siklus maksimun pada setiap stasiun yang ada. 
Berikut merupakan contoh perhitungan efisiensi stasiun kerja 3:

$$
\begin{aligned}
\text { Efisiensi Stasiun } & =\frac{W_{i}}{W_{s}} \times 100 \% \\
& =\frac{5.98}{7.89} \times 100 \% \\
& =76 \%
\end{aligned}
$$

Line efficiency usulan dihitung dengan menggunakan persamaan 4, diperoleh hasil sebagai berikut.

$$
\begin{aligned}
\text { Line Efficiency } & =\frac{\sum W i}{K \times C T} \times 100 \% \\
& =\frac{35.69}{6 \times 7,89} \times 100 \% \\
& =75.41 \%
\end{aligned}
$$

\begin{tabular}{|c|c|c|c|c|c|c|c|c|}
\hline $\begin{array}{c}\text { Stasiun } \\
\text { Kerja }\end{array}$ & $\begin{array}{c}\text { Elemen } \\
\text { Kerja }\end{array}$ & $\begin{array}{l}\text { Waktu Baku } \\
\text { (detik) }\end{array}$ & $\begin{array}{c}\text { Waktu Baku } \\
\text { Stasiun (detik) }\end{array}$ & $\begin{array}{c}\text { Efisiensi } \\
\text { Stasiun }\end{array}$ & $\begin{array}{c}\text { Line } \\
\text { Efficiency }\end{array}$ & $\begin{array}{c}\text { Balance } \\
\text { Delay }\end{array}$ & Idle Time & $\begin{array}{l}\text { Smoothness } \\
\text { Index }\end{array}$ \\
\hline \multirow{4}{*}{1} & 1 & 1,00 & \multirow{4}{*}{3,05} & \multirow{4}{*}{$39 \%$} & \multirow{27}{*}{$75,41 \%$} & \multirow{27}{*}{$24,59 \%$} & \multirow{4}{*}{4,84} & \\
\hline & 2 & 0,82 & & & & & & \\
\hline & 3 & 0,56 & & & & & & \\
\hline & 4 & 0,67 & & & & & & \\
\hline \multirow{2}{*}{2} & 5 & 5,03 & \multirow{2}{*}{5,98} & \multirow{2}{*}{$76 \%$} & & & \multirow{2}{*}{1,91} & \\
\hline & 6 & 0,95 & & & & & & \\
\hline \multirow{6}{*}{3} & 8 & 0,92 & \multirow{6}{*}{7,89} & \multirow{6}{*}{$100 \%$} & & & \multirow{6}{*}{0,00} & \\
\hline & 9 & 0,82 & & & & & & \\
\hline & 7 & 0,59 & & & & & & \\
\hline & 10 & 1,31 & & & & & & \\
\hline & 11 & 3,64 & & & & & & \\
\hline & 12 & 0,61 & & & & & & \\
\hline \multirow{4}{*}{4} & 13 & 0,67 & \multirow{4}{*}{4,96} & \multirow{4}{*}{$63 \%$} & & & \multirow{4}{*}{2,93} & \\
\hline & 14 & 0,61 & & & & & & 6,28 \\
\hline & 15 & 0,69 & & & & & & \\
\hline & 16 & 2,99 & & & & & & \\
\hline \multirow{4}{*}{5} & 17 & 1,66 & \multirow{4}{*}{5,95} & \multirow{4}{*}{$75 \%$} & & & \multirow{4}{*}{1,94} & \\
\hline & 19 & 1,75 & & & & & & \\
\hline & 18 & 0,94 & & & & & & \\
\hline & 20 & 1,60 & & & & & & \\
\hline \multirow{7}{*}{6} & 21 & 1,67 & \multirow{7}{*}{7,87} & \multirow{7}{*}{$100 \%$} & & & \multirow{7}{*}{0,02} & \\
\hline & 22 & 1,05 & & & & & & \\
\hline & 23 & 4,52 & & & & & & \\
\hline & 24 & 0,22 & & & & & & \\
\hline & 25 & 0,13 & & & & & & \\
\hline & 26 & 0,14 & & & & & & \\
\hline & 27 & 0,14 & & & & & & \\
\hline & & Minimum & 3,05 & & \multirow{3}{*}{\multicolumn{2}{|c|}{ Total Idle Time }} & 11,64 & \\
\hline & & Maksimum & 7,89 & & & & & \\
\hline & & Total & 35,69 & & & & & \\
\hline
\end{tabular}

Berdasarkan contoh Perhitungan di atas, maka dapat dilihat hasil dari perhitungan efisiensi tiap stasiun, line efficiency, balance delay, idle time, dan smoothness index pada masing-masing stasiun pada Tabel 6 sebgaai berikut.

Tabel 6. Perhitungan Efisiensi Stasiun, LE, BD, IT, dan SI Usulan pada Tablet XYZ

Dari hasil perhitungan line efficiency dengan menggunakan metode RPW, didapatkan nilai Line Efficiency pada Tablet XYZ sebesar $75.41 \%$. Lebih besarnya nilai line efficiency usulan dibanding yang awal disebabkan oleh pembagian elemen kerja yang merata pada tiap stasiun kerja, sehingga bottleneck menjadi berkurang dan produktivitas kerja meningkat karena beban kerja yang merata.

Urutan stasiun kerja usulan dapat digambarkan menggunakan precedence diagram usulan. Pembuatan precedence diagram usulan menggunakan data waktu baku tiap stasiun kerja yang telah diperbaiki. 


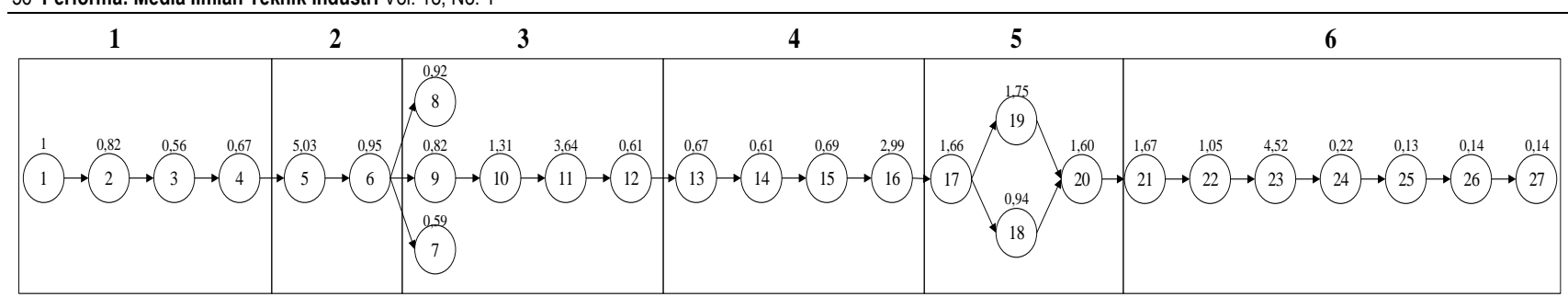

Gambar 2. Precedence Diagram Usulan Tablet XYZ

Berdasarkan atas perhitungan performansi pada kondisi awal dan kondisi usulan dengan metode RPW di atas, maka dapat diketahui perbandingan pada kedua kondisi sehingga dapat diketahui kondisi yang memiliki nilai line efficiency terbesar. Hasil perbandingan dapat dilihat pada Tabel 4.

Tabel 7. Perbandingan Line Efficiency Awal dan Usulan pada Tablet XYZ

\begin{tabular}{|c|c|c|c|c|c|}
\hline Kondisi & $\begin{array}{c}\text { Stasiun } \\
\text { Kerja }\end{array}$ & Efisiensi & $\begin{array}{c}\text { Idle } \\
\text { Time }\end{array}$ & $\begin{array}{c}\text { Balance } \\
\text { Delay }\end{array}$ & $\begin{array}{c}\text { Smoothing } \\
\text { Index }\end{array}$ \\
\hline Sebelum Perbaikan & 10 & $45,25 \%$ & 43,19 & $54,75 \%$ & 16,31 \\
\hline Sesudah Perbaikan & 6 & $75,41 \%$ & 11,64 & $24,59 \%$ & 6,28 \\
\hline
\end{tabular}

Perhitungan yang telah dilakukan terdapat perbedaan yang signifikan antara hasil perhitungan awal dan usulan. Perbedaan tersebut antara lain nilai line efficiency awal sebesar $45.25 \%$ dan usulan sebesar $75.41 \%$. Nilai line efficiency setelah dilakukan usulan perbaikan menjadi meningkat sebesar $30.16 \%$. Maka, usulan yang diajukan tersebut telah berhasil meningkatkan nilai line efficiency pada proses packing Tablet XYZ.

\section{Simpulan}

1. Nilai line effiency hanya sebesar $45.25 \%$, balance delay sebesar $54.75 \%$, total idle time sebesar 43.19 detik, serta smoothness index sebesar 16.31. Berdasarkan perhitungan tersebut, terbukti bahwa terjadinya bottleneck pada line packing salah satunya disebabkan oleh rendahnya nilai efisiensi stasiun kerja.

2. Penyebab bottleneck ada tujuh faktor diantaranya adalah motivasi kerja operator rendah, beban kerja operator tidak merata, strip datang terlambat, kualitas tablet tidak baik, tidak melaksakan SOP yang berlaku, mesin printing mudah tergeser, sehingga harus melakukan set up ulang, dan ruangan untuk bekerja bersuhu panas.

3. Dapat diketahui bahwa line balancing usulan pada Tablet XYZ dengan menggunakan metode Ranked Positional Weight (RPW) mengalami peningkatan nilai efisiensi, yaitu nilai line effiency sebesar $75.41 \%$, balance delay sebesar $24.59 \%$, total idle time sebesar 11.64 detik, serta smoothness index sebesar 6.28 .

\section{Daftar Pustaka}

Baroto, T. (2002). Perencanaan dan Pengendalian Produksi. Jakarta: Ghalia Indonesia.

Djunaidi, M., \& Angga. (2017). Analisis Keseimbangan Lintasan (Line Balancing) Pada Proses Perakitan Body Bus Pada Karoseri Guna Meningkatkan Efisiensi Lintasan. Jurnal Ilmiah Teknik Industri, 5(2), 77-84.

Dzikrillah, H. Purba, D. Suwazan, and N. Wahjoedi, Pengendalian Persediaan Melalui Persediaan Melalui Penentuan Produk Strategi, J@ti Undip : Jurnal Teknik Industri, vol. 11, no. 3, pp. 161-166.

Ekoanindiyo, F. A., \& Helmy, L. (2017, Januari). Meningkatkan Efisiensi Lintasan Kerja Menggunakan Metode RPW dan Killbridge-Western. Dinamila Teknik, 10 (1), 1626.

Fudianto, D., \& Munir, M. (2017, Oktober 17). Rancangan Keseimbangan Lintasan Stasiun Kerja Guna Meningkatkan Efisiensi Waktu Siklus Operasi Produk Es Balok. Journal Knowledge Industrial Engineering, 1(3). Retrieved from http://jurnal.yudharta.ac.id/v2/index.php/jki

Montororing, Y. D. (2018). Coating, Usulan Penentuan Waktu Baku Proses Racking Produk Amplimesh dengan Metode Jam Henti Pada Departemen Powder. Jurnal Teknik: Universitas Muhammadiyah Tangerang, 53-63.

Nasution, A. H. (1999). Perencanaan dan Pengendalian Produksi. Jakarta: Guna Widya.

Pratama, F. Y. (2018). Analisis Keseimbangan Lintasan Produksi Pada Kelompok Kerja Backpost And RIB Menggunakan Metode Ranked Positional Weight.. Yogyakarta: Universitas Islam Indonesia. 
Purwandhito, P. A., \& Nugroho, S. (2015). Analisis Penyebab Kegagalan Produksi Batu Bata Hasil Mesin Extruder dengan menggunakan Metode FTA (Fault Tree Analysis). Industrial Engineering Online Journal, 4.

Rachman, T. (2015, Oktober). Penentuan Keseimbangan Lintasan Optimal dengan Menggunakan Metode Heuristik. Jurnal Inovisi, 11(2), 67-83.

Saiful, S., Hambali , M., \& Rahman, T. M. (2014). Penyeimbangan Lintasan Produksi Dengan Metode Heuristik (Studi Kasus PT. XYZ Makassar). Jurnal Teknik Industri, 5(2), 182-189.

Sutalaksana, I. Z. (2006). Teknik Perancangan Sistem Kerja. Bandung: Institut Teknologi Bandung.

Wignjosoebroto, S. (2000). Ergonomi Studi Gerak dan Waktu: Teknik Analisis untuk Peningkatan Produktivitas Kerja. Surabaya: Guna Widya. 